Article

\title{
The Impact of Imitation Strategies, Managerial and Entrepreneurial Skills on Startups' Entrepreneurial Innovation
}

\author{
Panagiotis Tsolakidis ${ }^{1}$, Naoum Mylonas ${ }^{2, *}$ and Eugenia Petridou ${ }^{1}$ \\ 1 Department of Economics, Aristotle University of Thessaloniki, University Campus, \\ 54124 Thessaloniki, Greece; tsolakpa@econ.auth.gr (P.T.); evpet@econ.auth.gr (E.P.) \\ 2 Department of Tourism, Ionian University, P. Armeni Vraila 4, 49100 Corfu, Greece \\ * Correspondence: naoumyl@hotmail.com
}

Received: 26 July 2020; Accepted: 23 September 2020; Published: 6 October 2020

check for updates

\begin{abstract}
The scope of this paper is to investigate whether imitation strategies adopted by startups are effective in the pursuit of enhanced entrepreneurial innovation. To this end, a literature review was carried out in order to develop a research framework with factors related to imitation predicting entrepreneurial innovation. Moreover, managerial skills and entrepreneurial skills were incorporated as predictors of entrepreneurial innovation. In this respect, a structured questionnaire was developed to address these research objectives, based on scales tested in previous studies. In 2020, a survey was conducted on 486 startup owners operating in Greece, and a total of 289 responses were received. A hierarchical regression analysis was employed in order to examine the research framework. In congruence with the hypotheses, the findings demonstrated that outcome-based imitation strategies and trait-based imitation strategies positively affect the development of entrepreneurial innovation. Moreover, the positive impact of managerial and entrepreneurial skills on the development of entrepreneurial innovation was also confirmed. In contrast, the findings suggest that frequency-based imitation strategies negatively predict entrepreneurial innovation. However, outcome-based imitation and trait-based imitation strategies have been shown as the determinants with a positive impact on entrepreneurial innovation.
\end{abstract}

Keywords: outcome-based imitation; trait-based imitation; frequency-based imitation; innovation; managerial skills; entrepreneurial skills; startups

JEL Classification: L26; M13; O30

\section{Introduction}

A review of prior research reveals the critical role that imitation strategies play in a firm's competitive position compared to other successful firms (e.g., Schnaars 1994; Lieberman and Asaba 2006). Imitation strategies are defined as deliberate strategies by which firms aim to become similar to other successful firms, by attempting to achieve shared norms that enhance resource integration and coproduction (Haunschild and Miner 1997; Aarstad et al. 2010). In parallel, an imitation strategy enforces a firm's expectation, potentially naively, to acquire benefits similar to other innovative firms within the same sector (e.g., Zhou 2006; Aarstad et al. 2010). Prior research shows that a firm that adopts targeted and well-designed imitation strategies can benefit indirectly through a learning process (e.g., Dimaggio and Powell 1983; Cohen and Levinthal 1990; Aarstad et al. 2010) and can make changes and improvements within the business environment. In addition, a firm that imitates other firms' good practices and strategies creatively is in a position to generate innovative and enriched products and services (e.g., Schnaars 1994; Shankar et al. 1998). As an indicative example of an imitation strategy, 
we consider the case of Japanese luxury cars in the late 1980s, when the Japanese auto sellers mimicked the German market leaders-Mercedes and BMW-by constructing the prestige models, Lexus (Toyota), Infiniti (Nissan) and Accura (Honda) (Schnaars 1994). Another example concerns Google, a second generation search engine that performed better and overcame first generation engines like Yahoo (Valdani and Arbore 2007). The scope of this study is to stress the association between imitation and entrepreneurial innovation in startups. This relationship is to be investigated by also taking into account the impact of the managerial and entrepreneurial skills of the startups' owners. In this regard, the startups' owners should pay enough attention in developing managerial and entrepreneurial skills in order to delegate responsibility for particular areas such as planning, organizing, leading and controlling and eventually to improve his/her performance (Papulová and Mokroš 2007).

To date, a very limited number of empirical studies have examined the role of imitation strategies in entrepreneurial innovation in firms (e.g., Kim et al. 2004; Dobson and Safarian 2008; Ethiraj et al. 2008). Particularly, imitation strategies affect entrepreneurial innovation by providing imitators with the opportunity to identify a superior position, introduce improved products in order to better serve customers' needs and acquire newcomer competitors' know-how and experience through good practices like observation, benchmarking and competitor intelligence (Lane and Lubatkin 1998; Song 2015). Further, there is a void in the existing literature regarding this relationship in the domain of startups. Addressing this gap, this research sheds light on the relationship in the realm of startups between entrepreneurial innovation and different imitation strategies, managerial skills and entrepreneurial skills. In this vein, the contribution of this research lies in the effort towards establishing an appropriate framework for the evaluation of the degree to which a business activity of a startup relying on imitation elements is positioned to develop entrepreneurial innovation. A sample of startups operating in Greece was used for the purpose of this research.

This study analyzes the Greek ecosystem since significant progress was recorded recently in the digital transformation of the economy, which had a compellingly positive impact on innovation in Greek startups. According to the European Commission on Greece, in 2018, the country outperformed the European average in terms of investment in and access to financing for startups (EiT Digital 2018). Athens was recognized in 2018 as the European Capital of Innovation (EiT Digital 2018). At the same time, Greece climbed higher in the "Founders Choice" category as ranked by startup founders in their selections of foundation country of choice among EU countries. In particular, Athens, as an important breeding ground for startup innovation, moved 28 places higher in this category, in just one year, for the year 2018, among other major European capitals (EU Commission 2018). Furthermore, the startup innovation ecosystem in Greece, with its growing importance to the Greek economy, has also contributed to the selection of the research inquiry. The importance of startups operating in Greece is considered critical for the economy.

The present study contributes to the literature in two ways. Firstly, it explores whether specific imitation strategies, as defined in the research framework of Haunschild and Miner (1997), namely outcome-based (OBI), trait-based (TBI) and frequency-based (FBI) imitation, positively affect the development of startups' entrepreneurial innovation. Secondly, it examines whether managerial skills (MS) and entrepreneurial skills (ES) of startup entrepreneurs positively affect the development of entrepreneurial innovation.

\section{Theoretical Background}

\subsection{Entrepreneurial Innovation and Startups}

The importance of entrepreneurial innovation has been recognized since the late 2010s, when startups emerged as critical forms of entrepreneurial undertaking (e.g., Colombo and Piva 2008; Mustar et al. 2008; Neyens et al. 2010; Spender et al. 2017). A direct connection between entrepreneurial innovation and the sustainability and successful operation of startups has been extensively recognized (e.g., Acs and Audretsch 1990; Davila et al. 2003; Audretsch et al. 2006; Blank 
and Dorf 2012; Colombelli et al. 2016). Entrepreneurial innovation is defined as "the implementation of creative ideas through discovery and exploitation of opportunities in entrepreneurial firms" (Hung and Mondejar 2005, p. 120). Meanwhile, innovation is perceived as "a new idea, which may be a recombination of old ideas, a scheme that challenges the present order, a formula, or a unique approach which is perceived as new by the individuals involve" (Van de Ven 1986, p. 591).

An indicative definition of the startup business is provided by Blank (2010), who notes that a startup is a firm or a partnership of temporary duration, designed in such a way that seeks a repeatable and scalable business model. In the startup phase of the business scheme, innovative business ideas are incorporated by the market, which are transformed into practical and cost-effective applications. This repetition, continuous development, expansion and uninterrupted production of ideas is largely associated with the development of entrepreneurial innovation (e.g., Blank and Dorf 2012; Spender et al. 2017). A startup, as a new and dynamic firm in a market, often triggers proportionally dynamic changes, strengthens economic growth (Audretsch et al. 2006) and subsequently drives innovation (Koellinger and Thurik 2012). In terms of financial performance, startups seem to be generating profitable business ideas (Spender 2014). According to Wennekers and Thurik (1999) and Dejardin (2011), these firms play a key role in developing competition, causing new economic sectors to emerge and, consequently, in developing innovation.

However, the generation of innovation that emanates from the existence and operation of startups in markets is often suspended or hindered by adversity or limitations in their immediate external environment. According to Lévesque and Shepherd (2004), this adversity can be explained by taking into consideration the time it takes to enter a market, the inadequate assessment of competition within it and the geographical peculiarities of the market. Restrictions on startups also occur due to shortages of material and intangible resources (Wymer and Regan 2005) which adversely affect their innovation (Davila et al. 2003; Spender et al. 2017). Moreover, the uncertainty and high risk characterizing new markets and potential changes in the indirect external environment, like legislative and political changes, are also identified as being among the limitations (Sine et al. 2005). Finally, Watson et al. (1998) emphasize the generally vulnerable nature of startups in their efforts to grow into thriving and prosperous businesses.

\subsection{The Significance of Imitation in Startups}

Imitation can be viewed as a common type of behavior that is employed by many firms operating in various economic sectors (e.g., Sinclair 1990; Schnaars 1994; Song 2015). According to Haunschild and Miner (1997), imitation occurs when one or more firms mimic a successful practice of an innovative firm. It is also argued that many firms often imitate the processes and standards of innovative businesses in order to survive amidst the fierce competition (Weterings and Boschma 2009). Additionally, through imitation, they seek to establish themselves as well as their competitors have and to become recognizable (Rhee et al. 2006).

The process of improving or differentiating an innovative product or service by an imitator has already been addressed by Levitt (1966), who termed this "innovative imitation". This theoretical approach is one of the first attempts in illustrating the association between imitation and entrepreneurial innovation. The term "innovative imitation" is used in order to explain that the entry of new products and services in the market is attributed more to imitation rather than to innovation (Levitt 1966). Imitation is not only more extensively used, but it can be more effective than innovation for firms because they can invest more effectively in Research and Development (R\&D) and make more profits with the money saved by not initially investing in new product development. In this regard, certain scholars contend that in the context of a firm's R\&D, imitation and innovation occur simultaneously (e.g., Levitt 1966; Link and Neufeld 1986; Cohen and Levinthal 1989; Helpman 1993; Kim 1997). Many startups have oriented themselves towards adopting imitation policies or strategies to take the right decisions and ensure their successful entry and retention in new markets (Lévesque and Shepherd 2004). 
Furthermore, uncertainty in the business environment and risky decisions reinforce the inclination of business owners to develop imitative behavior (Haveman 1993; Greve 2000). The significance of imitation in startup businesses is further enhanced by their recognition of the need to acquire legitimacy, which can be gained by integrating well-established, widely accepted practices applied by dominant firms in the same sector (Meyer and Rowan 1977; Dimaggio and Powell 1983). Gentry et al. (2013), through the evaluation of other studies that support the adoption of imitation strategies by startups (e.g., Baum et al. 2000; Garcia Pont and Nohria 2002), concluded that these strategies have a significant impact on the operation of startups.

\subsection{Managerial and Entrepreneurial Skills in Startups}

Besides imitation, other factors also seem to contribute to the cultivation of innovation in startups. The development process of many startups is also often driven by human resources or skills (Teece et al. 1997; Zahra et al. 2000; Shane and Venkataraman 2000) that can be perceived as critical in recognizing and highlighting unique business opportunities. These human resources and skills are commonly referred to in the literature as "human capital" (Dougherty 1992; Castanias and Helfat 2001; Colombo and Grilli 2005; Guo et al. 2013; Fiore et al. 2019) or "managerial skills" and "entrepreneurial skills" possessed by entrepreneurs (Chandler and Hanks 1998). Drawing upon the definition given by Guo et al. (2013, p. 452), MS refer "to top managers' ability to effectively organize, allocate, and configure various firm resources," while ES "reflect the ability of top managers to sense and recognize entrepreneurial opportunities". Prior research has extensively revealed that both MS and ES of entrepreneurs are associated with entrepreneurial innovation (e.g., Subramaniam and Youndt 2005; Marvel and Lumpkin 2007; Tang et al. 2012), but only a few of them investigated theoretically and empirically this relationship in startups (e.g., Bates 1990; Cressy 1996; Honjo 2004; Colombo and Grilli 2005; Kato et al. 2015). The current study intends to enrich the literature by exploring the impact of MS and ES on startups' entrepreneurial innovation.

\section{Development of Research Hypotheses}

\subsection{Outcome-Based Imitation and Entrepreneurial Innovation}

OBI is defined as "the imitation of practices that appear to have had good outcomes for other firms in the past and avoiding practices with bad outcomes" (Haunschild and Miner 1997, p. 472). Imitators intend to enter certain established markets in order to benefit from introducing improved or differentiated products or by mimicking good outcomes coming from the innovators in the relative market (Shankar et al. 1998; Zhang and Markman 1998). Thus, each innovation is a recognizable and clearly defined outcome that can be further exploited under certain conditions by imitators (Schnaars 1994). Often, many markets in the early stages of an innovation are not ready to immediately absorb new products and services (Zhou 2006). In parallel, an innovative firm, for a significant time period after the introduction of an innovation, can stay inactive and be reluctant to adopt new changes or improvements to its production technology due to the fact that it has recently invested a lot of resources in knowledge and technology (Lieberman and Montgomery 1988). Based on these conditions, an imitator may address this gap by intervening in a partially developed market and introducing improved or partially differentiated products (Shankar et al. 1998).

Given that the original purpose of the imitator is frequently to fully copy an outcome, a differentiated design or specific improvements may emerge in practice. These differentiations and improvements enable the development of innovative products and services (Kim 1997; Shenkar 2010). Certain empirical studies (e.g., Cho et al. 1998; Weterings and Boschma 2009) argue that OBI strategies lead to entrepreneurial innovation through a process of learning and knowledge acquisition derived from the innovator's experience. Drawing upon Haunschild and Miner (1997), OBI can be perceived as creative adaptations of innovators' ideas via product redesign that may develop entrepreneurial innovation. Therefore, such an OBI can lead to entrepreneurial innovation, especially when the imitator 
profitably spots entrepreneurial innovations in order to gain knowledge and experience from them and to copy the good outcomes (Wu et al. 2019. Thus, we posit the following hypothesis:

Hypothesis 1 (H1). The OBI strategy is positively associated with entrepreneurial innovation.

\subsection{Trait-Based Imitation and Entrepreneurial Innovation}

Haunschild and Miner (1997, p. 472) defined TBI as "copying practices of other organizations with certain features". Additionally, TBI refers also to the selective replication of good practices used within an innovative firm (Haunschild and Miner 1997). Imitation based on traits seems to guide entrepreneurial innovation and this is reflected in several studies (e.g., Lane and Lubatkin 1998; Dobson and Safarian 2008; Ordanini et al. 2008; Song 2015) that highlight the contribution of this type of imitation to entrepreneurial innovation through a process of acquiring knowledge within the imitating firm. Based on Schnaars (1994) and Csaszar and Siggelkow (2010), TBI can encompass anything that relates to processes, good practices and optimal characteristics derived from other firms. Haunschild (1993) as well as Haunschild and Miner (1997) argued that TBI can be viewed as a type of social influence exerted from the innovator to the imitator. Likewise, seeking to acquire status by imitating higher-status firms can be included in TBI as a factor leading to entrepreneurial innovation (Fombrun and Shanley 1990). The impact of TBI on entrepreneurial innovation can be moderated by the capacity of the imitator to absorb good practices and the complexity of the business environment (Cohen and Levinthal 1990; Kogut and Zander 1992; Knott 2003). This association between TBI and entrepreneurial innovation can also be affected by certain firms' features such as the size, the prestige or their success of using a practice (Strang and Tuma 1993). Accordingly, we posit the following hypothesis:

Hypothesis 2 (H2). The TBI strategy is positively associated with entrepreneurial innovation.

\subsection{Frequency-Based Imitation and Entrepreneurial Innovation}

FBI is defined as "the organization's execution of practices previously used by large numbers of other organizations" (Haunschild and Miner 1997, p. 472). Imitators try to collect information regarding these practices in order to formulate new ideas and to enrich existing products or services (Kohli and Jaworski 1990; Darroch and McNaughton 2002). A business that imitates innovators on a frequent basis is learning unconsciously and is positively influenced by the exploitation of an extensive flow of information concerning innovation (Bolton 1993). The prospect of developing innovation through imitation based on frequency is also highlighted by Lieberman and Asaba (2006), who argue that in an environment of uncertainty and unpredictable market conditions, many business owners are receptive to information about repetitive actions done by innovative businesses. They even point out that this information is being used even if it is incomplete. Rogers (1995) and also Mansfield (1961) argue that the continuous imitation of innovative prototypes developed by other firms leads to the acquisition of more and more accurate information about the nature of entrepreneurial innovation. Additionally, according to Haunschild and Miner (1997), FBI creates new patterns that are articulated as repeated good business practices. Therefore, a firm that imitates on the basis of frequency can use these standards, as well as the information related to repeated behaviors of consumers and competitors, in order to be directed towards the generation of better products and services (Zhou and Wu 2010). Consequently, we posit the following hypothesis:

Hypothesis 3 (H3). The FBI strategy is positively associated with entrepreneurial innovation.

\subsection{Managerial Skills and Entrepreneurial Innovation}

MS of entrepreneurs as an integral part of a firm's intellectual capital can be perceived as a determining factor in the development of entrepreneurial innovation (e.g., Dougherty 1992; 
Tsai and Ghoshal 1998; Ahuja 2000; Subramaniam and Venkatraman 2001; Custódio et al. 2019; Fitjar and Pose 2013). According to Sirmon et al. (2011), the MS of entrepreneurs have the potential to promote entrepreneurial innovation by effectively coordinating business resources. Furthermore, the entrepreneur's MS ensure that an innovative firm can maintain its competitive advantage (Kraaijenbrink et al. 2010) and identify good business projects (Custódio et al. 2019). In the same vein, Zott and Amit (2010) argue that MS enable a firm to design profitable business models in order to appropriately exploit business opportunities. Finally, Guo et al. (2013) contend that MS enable managers to strategically exploit resources in order to develop novel business models as mechanisms to address issues related to entrepreneurial innovation. Therefore, we posit the following hypothesis:

Hypothesis 4 (H4). MS are positively associated with entrepreneurial innovation.

\subsection{Entrepreneurial Skills and Entrepreneurial Innovation}

Creativity and innovation can be viewed as catalyzing factors for a startup (Barringer and Ireland 2006). Based on Pretorius et al. (2005), creativity is an integral part of ES and is essential for the successful creation of an innovative business. Marvel and Lumpkin (2007) also highlighted the contribution of ES, such as experience, knowledge and technological training in the development of entrepreneurial innovation. In fact, the positive influence of knowledge as part of an entrepreneur's skills is pointed out in other studies (e.g., Shane 2000; Shepherd and DeTienne 2005; Thorpe et al. 2005). Furthermore, they support its catalyzing role in the search of opportunities for its potential to guide the innovative process of the firm. Innovation in a firm can be enforced through actions related to improving ES (Johnson et al. 2008; Bock et al. 2012). Indeed, George and Bock (2011) indicate that ES can enable a firm to redesign its business model. In the empirical study by Guo et al. (2013), the contribution of ES is equally recognized in the development of entrepreneurial innovation, as the skills are incorporated into the overall firm's human capital. This issue is also analyzed by Bygrave and Hofer (1991), who indicate that the ES of a business owner can enable him/her to spot market opportunities and to motivate their employees to engage more with their firms. Finally, ES are of significance in the transformation of unique entrepreneurial ideas into commercialized entrepreneurial initiatives (e.g., Shane and Venkataraman 2000; Baron and Ensley 2006; Short et al. 2010; Tang et al. 2012). Ultimately, both an entrepreneur's experience and their knowledge are all part of their ES that can enhance entrepreneurial innovation and generate positive business outcomes (e.g., Bates 1990; Gimeno et al. 1997; Staniewski 2016). Thus, we posit the following hypothesis:

Hypothesis 5 (H5). ES are positively associated with entrepreneurial innovation.

\section{Methodology}

\subsection{Data and Sample}

The sample of the study consists of startup entrepreneurs in Greece that conduct entrepreneurial activity in sectors drawing from the EiT Digital \& Foundation, Startups in Greece classification (2018), which is presented in Table 1.

Overall, 486 questionnaires were distributed and 289 were returned, generating a response rate of 59 percent. Given the absence of a national register of startups in Greece, questionnaires were distributed by the "snowball" method (e.g., Orhan and Scott 2001; Smith et al. 2012). As such, the authors contacted the subjects of the defined population by phone, email or social media to fill out the questionnaire and simultaneously asked them to indicate other eligible subjects. The sample consisted of startup entrepreneurs coming from different geographical areas of Greece. The majority of them derived from the Attica and Central Macedonia regions (Figure 1). 
Table 1. Distribution of the sample's startups in sectors.

\begin{tabular}{ccc}
\hline Sectors & Frequency & \% Relative Frequency \\
\hline Advertising & 15 & 5.19 \\
Agriculture/Agri-food & 13 & 4.50 \\
Blockchain/FinTech & 13 & 4.50 \\
Creative Industries/Smart Cities & 16 & 5.54 \\
Entertainment/Lifestyle & 20 & 6.92 \\
Finance & 22 & 7.61 \\
Financial Technology & 11 & 3.81 \\
Food \& Beverage & 13 & 4.50 \\
HealthTech & 16 & 5.54 \\
IT/Telecommunications & 23 & 7.96 \\
Logistics & 11 & 3.81 \\
Resource Management & 18 & 6.23 \\
Social Networking & 12 & 4.15 \\
Software & 19 & 6.57 \\
Technology/Artificial Intelligence & 25 & 8.65 \\
Tourism & 20 & 6.92 \\
Transportations & 13 & 4.50 \\
Other & 9 & 3.11 \\
\hline All & 289 & 100.00 \\
\hline
\end{tabular}

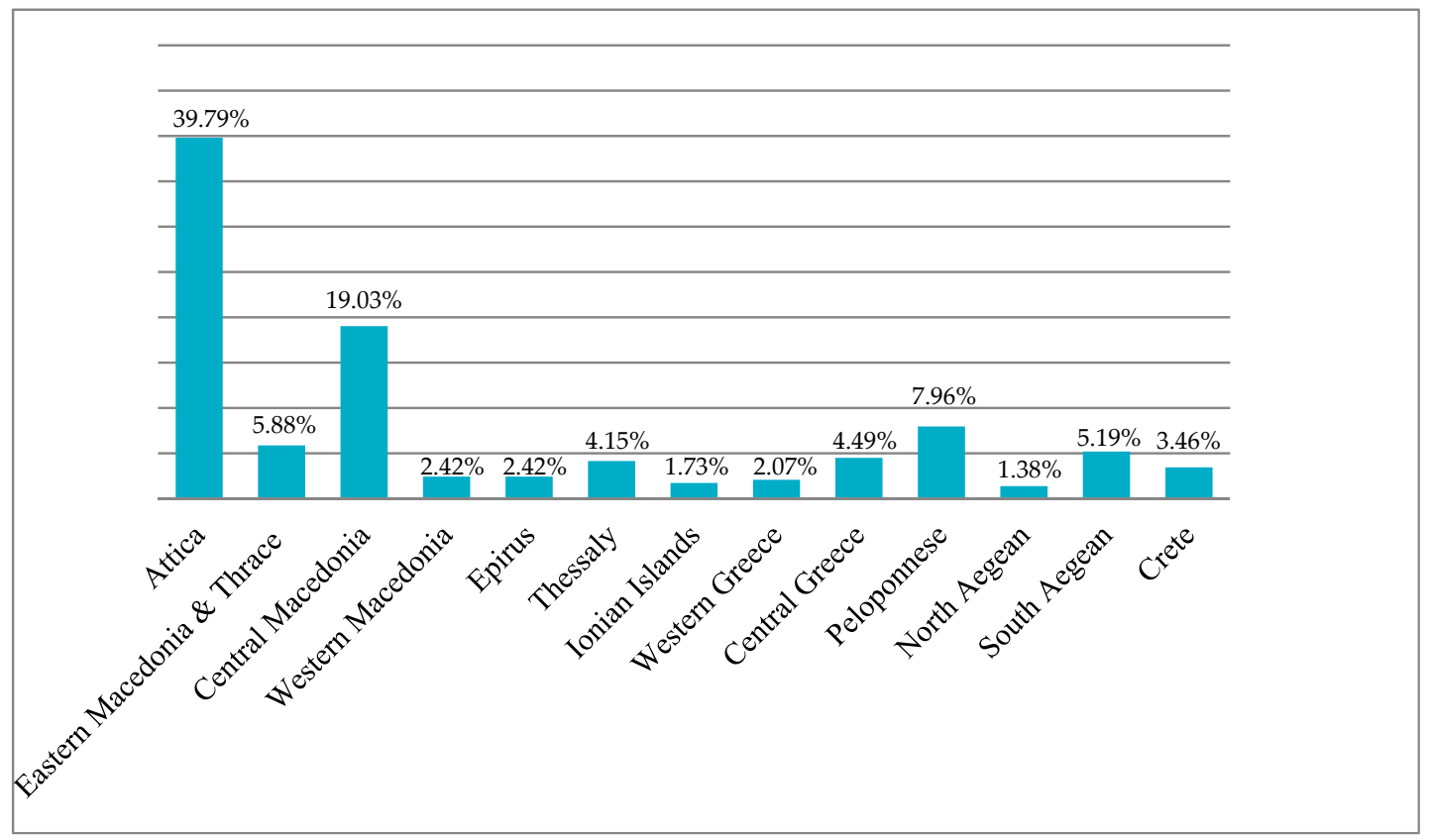

Figure 1. Distribution of the sample by region based on NUTS 2 classification.

With reference to the gender of the sample, there is a quite balanced distribution, as males account for $50.9 \%$ and females account for $49.1 \%$. Most startup entrepreneurs who responded to the questionnaire belong to the age group of 31-40 years old (40\%). An almost similar share (30\%) belongs to the 41-50 years old group. Approximately $14 \%$ belong to the age groups $18-30$ and $51-60$ years, but only $1 \%$ belong to the group of over 60 years old. With respect to the years of respondents' professional experience, $55.7 \%$ of startup entrepreneurs have 10 or more years, $34.6 \%$ have $4-9$ years, and $9.7 \%$ have 1-3 years. With reference to the respondents' educational level, the majority $(41.87 \%)$ hold a university or senior technological institution bachelor certificate or equivalent, and a similar percentage (39.44\%) hold a master diploma. Moreover, $13.15 \%$ of them are secondary education graduates, $5.19 \%$ of them hold a PhD title and only $0.35 \%$ are primary education graduates. Concerning the years of operation, 
$54 \%$ of the startups have operated for $4-9$ years, 33\% for $1-3$ years and $13 \%$ for 10 years. Lastly, the majority of startups (32.5\%) employ 4-8 individuals and the rest of the startups are equally divided into three categories in terms of individuals employed, namely 1-3, 9-15 and 16 or more employed.

\subsection{Measures}

All measures in this study (Table 2) used a seven-point Likert scale (1: strongly disagree and 7: strongly agree). All scale reliabilities were acceptable, exceeding the acceptable value of 0.70 recommended by Nunnally et al. (1967).

Table 2. Description of the regression variables.

\begin{tabular}{ccc}
\hline Type & Name & Definition \\
\hline Dependent & Entrepreneurial Innovation & $\begin{array}{c}\text { "The implementation of creative ideas through discovery and } \\
\text { exploitation of opportunities in entrepreneurial firms" (Hung } \\
\text { and Mondejar 2005, p. 120) }\end{array}$ \\
\hline Predictors & OBI & $\begin{array}{c}\text { "The imitation of practices that appear to have had good } \\
\text { outcomes for other firms in the past and avoiding practices } \\
\text { with bad outcomes" (Haunschild and Miner 1997, p. 472) }\end{array}$ \\
\hline TBI & $\begin{array}{c}\text { "Copying practices of other organizations with certain } \\
\text { features" (Haunschild and Miner 1997, p. 472) }\end{array}$ \\
\hline FB & $\begin{array}{c}\text { "The organization's execution of practices previously used by } \\
\text { large numbers of other organizations" (Haunschild and Miner } \\
\text { 1997, p. 472) }\end{array}$ \\
\hline ES & $\begin{array}{c}\text { "The ability to effectively organize, allocate, and configure } \\
\text { various firm resources" (Guo et al. 2013, p. 452) }\end{array}$ \\
\hline
\end{tabular}

Entrepreneurial innovation was assessed in our research by using the nine-item instrument named "business model innovation", developed by Guo et al. (2013). An example item for this scale is "Our entrepreneurial innovation provides new combinations of products, services and information". The Cronbach $\alpha$ for this variable was 0.94 .

The three types of strategic imitation, namely outcome-based, trait-based and frequency-based, were assessed by adopting the scale of Aarstad et al. (2018). A sample item for OBI is "If we observe that other firms offer high-quality products and services, we use these as role models to achieve the same in our firm". The Cronbach $\alpha$ for this construct was 0.95. A sample item for TBI is "We continually seek information about successful firms in the industry to get information about new products and services that may be relevant for our company". The Cronbach $\alpha$ for this construct was 0.92. A sample item for FBI is "We frequently implement methods for production and sales of products and services, which we observe to be common in numerous other firms in the industry". The Cronbach $\alpha$ for this construct was 0.93 .

Both MS and ES were measured by using the relevant constructs developed by Guo et al. (2013). A sample item for MS is "One of my greatest strengths is organizing resources and coordinating tasks". The Cronbach $\alpha$ for this construct was 0.93 . A sample item for ES is "'I frequently identify opportunities to start new businesses even though I may not pursue them". The Cronbach $\alpha$ for this construct was 0.95 .

We included as the sample's control variables the following: number of employees (1: 1-3, 2: 4-8, 3: 9-15, 4: more than 16 employees), years of operation (Lee and Zhou 2012) (1: 1-3, 2: 4-9, 3: more than 10 years), owner gender (1: male, 2: female), owner age (1: 18-30, 2: 31-40, 3: 41-50, 4: 51-60, 5: more than 60 years), owner educational status (1: primary education graduate, 2: secondary education graduate, 3: tertiary education graduate, 4: postgraduate studies holder, 5: doctoral degree) and owner work experience (1: 1-3, 2: 4-9, 3: more than 10 years). 


\subsection{Data Analyses}

Principal axis factoring was employed to confirm construct validity and then to export as factors all of the six constructs of the current research framework. Most items were loaded significantly on their respective factors (Appendix A) The normality Kolmogorov-Smirnov test was used to assess all items. The Kaiser-Meyer-Olkin (KMO) measure of sampling adequacy was highly accepted (0.915) and Bartlett's test of sphericity was accepted as it was statistically significant $(<0.001)$. The Durbin-Watson statistic index was 2.217, which is close to the 1.5-2.5 range of acceptable values; thus, the assumption of independent errors is tenable. A hierarchical analysis was conducted in order to test the hypotheses of the current research. The control variables were entered in the first step and the main effect independent variables were incorporated in the second step. Table 2 presents mean scores and standard deviations of all the variables used. Overall, the average value of entrepreneurial innovation was 5.08; the average values of the OBI and TBI were almost similar at 4.33 and 4.49 , respectively. Meanwhile, the average value of the FBI was 3.94. The average value of MS reached 5.02 and the ES were recorded at an average value of 5.20 (Table 3).

Table 3. Descriptive Information of the Variables.

\begin{tabular}{ccccccc}
\hline Variables & Observations & Mean & Median & S.D. & Min & Max \\
\hline Entrepreneurial & 289 & 5.08 & 5.33 & 1.24 & 1.11 & 7.00 \\
Innovation & 289 & 4.33 & 4.60 & 1.41 & 1.00 & 7.00 \\
OBI & 289 & 4.49 & 4.67 & 1.37 & 1.33 & 7.00 \\
TBI & 289 & 3.94 & 3.88 & 1.44 & 1.00 & 6.88 \\
FBI & 289 & 5.02 & 5.20 & 1.19 & 1.00 & 7.00 \\
MS & 289 & 5.20 & 5.40 & 1.18 & 1.00 & 7.00 \\
ES & 289 & 2.36 & 2.00 & 1.08 & 1.00 & 4.00 \\
Number of & 289 & 1.80 & 2.00 & 0.65 & 1.00 & 3.00 \\
Employees & 289 & 1.49 & 1.00 & 0.50 & 1.00 & 2.00 \\
Years of Operation & 289 & 2.47 & 2.00 & 0.92 & 1.00 & 5.00 \\
Gender & 289 & 3.35 & 3.00 & 0.75 & 1.00 & 5.00 \\
Age & 289 & 2.46 & 3.00 & 0.67 & 1.00 & 3.00 \\
Owner Educational & & & & & & \\
Background & & & & & &
\end{tabular}

\section{Results}

Table 4 displays the results of the hierarchical multiple regression analysis by providing the standardized beta coefficients, the $\mathrm{R}^{2}$ values and the ANOVA test. Firstly, the variance explained by the predicting variables in model 2 is acceptable $\left(\mathrm{R}^{2}=0.225\right)$ and statistically significant $(p \leq$ 0.001) (Falk and Miller 1992). Moreover, the outcomes of the ANOVA test are acceptable. The results from the first step of the hierarchical regression analysis indicate that only owner educational background has a strong statistically significant relationship with entrepreneurial innovation. The results of the second step exhibit that predicting variables exert a statistically significant positive effect on entrepreneurial innovation, with the exception of FBI. Additionally, the incremental variance explained by the predicting variables was statistically significant $\left(\Delta \mathrm{R}^{2}=0.193, p \leq 0.001\right)$. Therefore, $\mathrm{H} 1, \mathrm{H} 2, \mathrm{H} 4$ and $\mathrm{H} 5$ are supported by the findings of the linear regression analysis, while $\mathrm{H} 3$ is not supported. Notably, for H3, the beta coefficient of the FBI variable is statistically significant on the dependent variable, but it exerts a negative impact contrary to $\mathrm{H} 3$ hypothesis argumentation. 
Table 4. Regression analyses.

\begin{tabular}{|c|c|c|c|c|}
\hline \multirow{2}{*}{$\begin{array}{c}\text { Variable } \\
\text { OBI }\end{array}$} & \multicolumn{2}{|c|}{ Model 1} & \multicolumn{2}{|c|}{ Model 2} \\
\hline & & & $0.081 *$ & $(0.066)$ \\
\hline TBI & & & $0.187^{* *}$ & $(0.064)$ \\
\hline FBI & & & $-0.179^{* *}$ & $(0.064)$ \\
\hline MS & & & $0.268^{* * *}$ & (0.073) \\
\hline ES & & & $0.152 *$ & $(0.074)$ \\
\hline $\begin{array}{l}\text { Number of } \\
\text { Employees }\end{array}$ & -0.094 & $(0.082)$ & -0.107 & $(0.074)$ \\
\hline Years of Operation & -0.049 & $(0.140)$ & -0.110 & $(0.128)$ \\
\hline Gender & -0.167 & $(0.148)$ & -0.072 & $(0.134)$ \\
\hline Age & 0.039 & $(0.106)$ & 0.026 & (0.096) \\
\hline $\begin{array}{l}\text { Owner Educational } \\
\text { Background }\end{array}$ & 0.244 * & $(0.098)$ & 0.145 & $(0.090)$ \\
\hline $\begin{array}{l}\text { Owner Work } \\
\text { Experience }\end{array}$ & -0.120 & $(0.155)$ & -0.040 & $(0.140)$ \\
\hline Constant & 5.026 & $(0.477)$ & 2.573 & $(0.560)$ \\
\hline Observations & 289 & & 289 & \\
\hline Prob $>$ F & 0.152 & & 0.000 & \\
\hline $\mathrm{R}$-squared & 0.033 & & 0.225 & \\
\hline Adj R-squared & 0.012 & & 0.194 & \\
\hline
\end{tabular}

\section{Discussion and Conclusions}

The main objective of this research was to investigate the extent to which a startup, by adopting imitation policies and strategies, can enforce entrepreneurial innovation by taking into consideration the simultaneous impact of the MS and ES of the startup business owners. The exploration of the positive effect of imitation strategies on entrepreneurial innovation was carried out in previous theoretical and empirical studies (e.g., Levitt 1966; Schnaars 1994; Cho et al. 1998; Niosi 1999; Dobson and Safarian 2008; Weterings and Boschma 2009; Song 2015). Nevertheless, none of the previous studies established hypotheses or findings in the field of startups related to the association between imitation strategies and entrepreneurial innovation. Particularly, the current research used startups operating in Greece as a sample. The contribution of this research was based on the need to identify the effects of imitation strategies on innovation, not only in the usual field of commodity production but also by addressing the traits of a business in terms of its functions and practices. In addition, this research expected to enrich the under-examined literature about the impact of imitation on entrepreneurial innovation.

The typology of imitation strategies by Haunschild and Miner (1997) was adopted in order to achieve this research scope, due to the fact that it was not only thorough in approaching the reality but also referred to certain subsequent scientific studies related to imitation. In particular, the following findings emerged. Firstly, the OBI strategy on the development of entrepreneurial innovation was confirmed as significant. This finding is in the direction of the recent empirical study conducted by Wu et al. (2019) which examined Chinese manufacturing firms and concluded that imitation strategy, based on accumulative improvements from existing products and technologies, is positively related to innovation. Secondly, the TBI strategy was found to be positively connected with entrepreneurial innovation and confirmed previous empirical studies (e.g., Dobson and Safarian 2008; Song 2015). Thirdly, the hypothesized positive effect of FBI on the development of entrepreneurial innovation was not accepted, because a statistically significant negative effect was noticed. This finding is thought to be caused by the weakening of innovation due to its high level of mimicking by numerous firms. The previous finding is in line with the empirical research by Aarstad et al. (2018) on imitation strategies and inter-firm networks in the tourism industry. Moreover, the positive impact of MS and ES on the development of entrepreneurial innovation is statistically confirmed in the current study. Notably, in terms of MS, the findings of this study follow those of Guo et al. (2013) 
and Subramaniam and Youndt (2005). Meanwhile, in terms of ES, the findings coincide with several empirical studies (e.g., Marvel and Lumpkin 2007; Tang et al. 2012; Guo et al. 2013).

The current findings provide practical implications and lessons for startup entrepreneurs to be aware of the benefits of OBI and TBI strategies and the drawbacks of FBI strategy in regard to entrepreneurial innovation development and management. In parallel, it seems that the cultivation of MS and ES is of high importance to startup entrepreneurs in order to have a competitive advantage in entrepreneurial innovation integration into their businesses. Similarly, startup owners' educational status is highlighted in this study as a supplementary determinant to entrepreneurial innovation. In conclusion, it is obvious that the MS exert the highest predictive effect on the development of entrepreneurial innovation. This result may also derive from the fact that startup owners who are familiar with managerial practices and tools are in a better position to develop new ventures and to ensure their sustainability. This reveals the necessity for new startup entrepreneurs to invest more in acquiring MS and to be constantly informed about updated good management practices. The latter can be achieved in entrepreneurial learning programs targeted at existing or potential startup entrepreneurs. Provided that startup entrepreneurship is a driving force for the economy of a country, it is of high importance for governments and the European Union to support their entrepreneurial initiatives through educational and financial programs, incubators and mentoring.

\section{Limitations and Future Research}

In the present research, several limitations have been identified. Firstly, whereas this study examines the startups' imitation strategies, it relies on practices of large and established firms reviewed in the literature that enhanced the entrepreneurial innovation (Gentry et al. 2013). Secondly, a potential problem with the generalizability of the results also exists because the data were collected from startup entrepreneurs who live and conduct entrepreneurial activity in Greece. In fact, the majority of questionnaires were collected from the two largest regions of Greece (Attica and Central Macedonia). Thirdly, a "snowball" sampling method instead of a nonrandom method was adopted in order to collect data, due to the lack of any register or email list including the names and contact information of startups in Greece. Although a relatively large sample was used, certain limitations and a generation of bias may exist in the used sampling approach of the population (e.g., Faugier and Sargeant 1997; Heckathorn 1997). Fourthly, the single source and self-report nature of the data may have enabled the presence of the common method bias.

The interesting topic concerning the impact of imitation strategies on entrepreneurial innovation paves the way to a deeper analysis in subsequent research. The ways in which imitation is connected with entrepreneurial innovation and its multiple dimensions are likely to attract the attention of many researchers in the future. In addition, the research hypotheses developed for this model can be tested in particular sectors of startups or in other countries or in a cross-cultural design in order to examine if this research has universal, generalizable value in all sectors or to point out potential differences. Likewise, the participation in business networks and structures to support and expand entrepreneurship and as well as the imitator's absorbing capacity of good practices and the business environment complexity (e.g., Cohen and Levinthal 1990; Kogut and Zander 1992; Knott 2003) may be empirically tested as a moderating or mediating variable in the relationship between imitation and innovation in startups. In addition, future research can address the contribution of imitation on firms' performance following prior research (e.g., March and Olsen 1976; Dimaggio and Powell 1983; Tsui and Si 2003; Aarstad et al. 2010). Since several studies (e.g., Lackéus and Middleton 2015) found a positive impact of entrepreneurial education on startup creations, future studies can include a variable related to entrepreneurial education in similar analyses. Given the fact that incubators play an important role in fostering the creation and development of startups (e.g., Aernoudt 2004; Mian et al. 2016), future research can also include a variable related to whether the startup has been supported by an incubator or not in similar analyses. 
Author Contributions: Conceptualization, P.T. and E.P.; methodology, P.T. and N.M.; software, P.T. and N.M.; validation, P.T., N.M. and E.P.; formal analysis, P.T. and N.M.; investigation, P.T.; resources, N.M.; data curation, P.T.; writing-original draft preparation, P.T. and N.M.; writing—review and editing, P.T. and N.M.; visualization, P.T. and N.M.; supervision, E.P. All authors have read and agreed to the published version of the manuscript.

Funding: This research received no external funding.

Acknowledgments: The authors would like to thank the anonymous reviewers for their precious comments and recommendations; the pre-incubator of the Municipality of Thessaloniki "OK!Thess" and "Employment and Career Structure" of the Aristotle University of Thessaloniki for their support in questionnaires allocation; and also Emily Fisher (emilyfisher414@gmail.com) for the language editing of the final manuscript.

Conflicts of Interest: The authors declare no conflict of interest.

\section{Appendix A}

Table A1. Results of Factor Analysis.

\begin{tabular}{|c|c|c|c|c|c|c|}
\hline Items & 1 & 2 & 3 & 4 & 5 & 6 \\
\hline EINNOV1 & 0.733 & & & & & \\
\hline EINNOV2 & 0.762 & & & & & \\
\hline EINNOV3 & 0.790 & & & & & \\
\hline EINNOV4 & 0.833 & & & & & \\
\hline EINNOV5 & 0.821 & & & & & \\
\hline EINNOV6 & 0.802 & & & & & \\
\hline EINNOV7 & 0.768 & & & & & \\
\hline EINNOV8 & 0.809 & & & & & \\
\hline EINNOV9 & 0.778 & & & & & \\
\hline OBI1 & & & & & 0.824 & \\
\hline OBI2 & & & & & 0.777 & \\
\hline OBI3 & & & & & 0.756 & \\
\hline OBI4 & & & & & 0.771 & \\
\hline OBI5 & & & & & 0.804 & \\
\hline TBI1 & & & 0.725 & & & \\
\hline TBI2 & & & 0.801 & & & \\
\hline TBI3 & & & 0.797 & & & \\
\hline TBI4 & & & 0.791 & & & \\
\hline TBI5 & & & 0.756 & & & \\
\hline TBI6 & & & 0.786 & & & \\
\hline FBI1 & & 0.641 & & & & \\
\hline FBI2 & & 0.619 & & & & \\
\hline FBI3 & & 0.807 & & & & \\
\hline FBI4 & & 0.852 & & & & \\
\hline FBI5 & & 0.812 & & & & \\
\hline FBI6 & & 0.837 & & & & \\
\hline FBI7 & & 0.760 & & & & \\
\hline FBI8 & & 0.767 & & & & \\
\hline MS1 & & & & & & 0.690 \\
\hline MS2 & & & & & & 0.786 \\
\hline MS3 & & & & & & 0.828 \\
\hline MS4 & & & & & & 0.813 \\
\hline MS5 & & & & & & 0.723 \\
\hline ES1 & & & & 0.780 & & \\
\hline ES2 & & & & 0.842 & & \\
\hline ES3 & & & & 0.859 & & \\
\hline ES4 & & & & 0.785 & & \\
\hline ES5 & & & & 0.801 & & \\
\hline
\end{tabular}

Note: EINNOV = Entrepreneurial Innovation; OBI = Outcome-Based Imitation; TBI = Trait-Based Imitation; FBI $=$ Frequency-Based Imitation; MS = Managerial Skills; ES = Entrepreneurial Skills . 


\section{References}

Aarstad, Jarle, Havard Ness, Sven A. Haugland, and Olav Andreas Kvitastein. 2018. Imitation Strategies and Interfirm Networks in the Tourism Industry: A structure-Agency approach. Journal of Destination Marketing $\mathcal{E}$ Management 9: 166-74.

Aarstad, Jarle, Sven A. Haugland, and Arent Greve. 2010. Performance Spillover Effects in Entrepreneurial Networks: Assessing a dyadic theory of social capital. Entrepreneurship Theory and Practice 34: 1003-20. [CrossRef]

Acs, Zoltan J., and David B. Audretsch. 1990. Innovation and Small Firms. Cambridge: MIT Press.

Aernoudt, Rudy. 2004. Incubators: Tool for Entrepreneurship? Small Business Economics 23: 127-35. [CrossRef]

Ahuja, Gautam. 2000. Collaborative networks, structural holes, and innovation: A longitudinal study. Administrative Science Quarterly 45: 425-55. [CrossRef]

Audretsch, David B., Max Keilbach, and Erik Lehmann. 2006. Entrepreneurship and Economic Growth. Oxford: Oxford University Press.

Baron, Robert, and Michael Ensley. 2006. Opportunity Recognition as the Detection of Meaningful Patterns: Evidence from Comparisons of Novice and Experienced Entrepreneurs. Management Science 52: 1331-44. [CrossRef]

Barringer, Bruce, and R. Duane Ireland. 2006. Entrepreneurship: Successfully Launching New Ventures. Upper Saddle River: Pearson Prentice Hall.

Bates, Timothy. 1990. Entrepreneur human capital inputs and small business longevity. Review of Economics and Statistics 72: 551-59. [CrossRef]

Baum, Joel, Tony Calabrese, and Brian Silverman. 2000. Don't go it alone: Alliance Network Composition and Startups' Performance in Canadian Biotechnology. Strategic Management Journal 21: 267-94. [CrossRef]

Blank, Steve, and Bob Dorf. 2012. The Startup Owner's Manual: The Step-by-Step Guide for Building a Great Company. Hoboken: John Wiley Sons.

Blank, Steve. 2010. Why Startups Are Agile and Opportunistic-Pivoting the Business Model. Available online: www.steveblank.com (accessed on 5 May 2020).

Bock, Adam, Tore Opsahl, Gerard George, and David Gann. 2012. The effects of culture and structure on strategic flexibility during business model innovation. Journal of Management Studies 49: 279-305. [CrossRef]

Bolton, Michele Kremen. 1993. Imitation versus innovation: Lessons to be learned from the Japanese. Organizational Dynamics 21: 30-45. [CrossRef]

Bygrave, William, and Charles Hofer. 1991. Theorizing about entrepreneurship. Entrepreneurship Theory and Practice 16: 13-22. [CrossRef]

Castanias, Richard, and Constance Helfat. 2001. The managerial rents model: Theory and empirical analysis. Journal of Management 27: 661-78. [CrossRef]

Chandler, Gaylen, and Steven Hanks. 1998. An examination of the substitutability of founders' human and financial capital in emerging business ventures. Journal of Business Venturing 13: 353-69. [CrossRef]

Cho, Dong Sung, Dong Jae Kim, and Dong Kee Rhee. 1998. Latecomer strategies: Evidence from the semiconductor industry in Japan and Korea. Organization Science 9: 489-505. [CrossRef]

Cohen, Wesley, and Daniel Levinthal. 1989. Innovation and Learning: The two faces of R\&D. The Economic Journal 99: 569-96.

Cohen, Wesley, and Daniel Levinthal. 1990. Absorptive Capacity: A New Perspective on Learning and Innovation. Administrative Science Quarterly 35: 128-52. [CrossRef]

Colombelli, Alessandra, Jackie Krafft, and Marco Vivarelli. 2016. To be born is not enough: The key role of innovative start-ups. Small Business Economics 47: 277-91. [CrossRef]

Colombo, Massimo, and Evila Piva. 2008. Strengths and weaknesses of academic start-ups: A conceptual model. IEEE Transactions on Engineering Management 55: 37-49. [CrossRef]

Colombo, Massimo, and Luca Grilli. 2005. Founders' Human Capital and the Growth of New Technology-Based Firms: A Competence-Based View. Research Policy 34: 795-816. [CrossRef]

Cressy, Robert. 1996. Are Business Startups Debt-Rationed? Economic Journal 106: 1253-70. [CrossRef]

Csaszar, Felipe, and Nicolaj Siggelkow. 2010. How much to copy? Determinants of Effective Imitation Breadth. Organization Science 21: 661-76. [CrossRef] 
Custódio, Cláudia, Miguel Ferreira, and Pedro Matos. 2019. Do General Managerial Skills Spur Innovation. Management Science 65: 459-76.

Darroch, Jenny, and Rod McNaughton. 2002. Examining the link between knowledge management practices and types of innovation. Journal of Intellectual Capital 3: 210-22. [CrossRef]

Davila, Antonio, George Foster, and Mahendra Gupta. 2003. Venture capital financing and the growth of startup firms. Journal of Business Venturing 18: 689-709. [CrossRef]

Dejardin, Marcus. 2011. Linking net entry to regional economic growth. Small Business Economics 36: $443-60$. [CrossRef]

Dimaggio, Paul, and Walter Powell. 1983. The iron cage revisited: Institutional isomorphism and collective rationality in organizational fields. American Sociological Review 48: 147-60. [CrossRef]

Dobson, Wendy, and A. E. Safarian. 2008. The transition from imitation to innovation: An enquiry into China's evolving institutions and firm capabilities. Journal of Asian Economics 19: 301-11. [CrossRef]

Dougherty, Deborah. 1992. Interpretive barriers to successful product innovation in large firms. Organization Science 3: 179-203. [CrossRef]

EiT Digital. 2018. Startups in Greece 2018. Athens:FOUND.ATION. Available online: file://C:/Users/MMNew/ Downloads/Startups-in-Greece-2018-by-EIT-Digital-and-Foundation.pdf (accessed on 10 August 2018).

Ethiraj, Sendil, Daniel Levinthal, and Rishi Roy. 2008. The dual role of modularity: Innovation and imitation. Management Science 54: 939-55. [CrossRef]

EU Commission. 2018. European Startup Initiative, Startup Heatmap Europe. Available online: https: //www.startupheatmap.eu (accessed on 4 October 2018).

Falk, Frank, and Nancy Miller. 1992. A Primer for Soft Modeling. Akron: University of Akron Press.

Faugier, Jean, and Mary Sargeant. 1997. Sampling hard to reach populations. Journal of Advanced Nursing 26: 790-97. [CrossRef]

Fiore, Eleonora, Giuliano Sansone, and Emilio Paolucci. 2019. Entrepreneurship education in a multidisciplinary environment: Evidence from an entrepreneurship programme held in Turin. Administrative Sciences 9: 28. [CrossRef]

Fitjar, Rune Dahl, and Andrés Rodríguez Pose. 2013. Firm collaboration and modes of innovation in Norway. Research Policy 42: 128-38. [CrossRef]

Fombrun, Charles, and Mark Shanley. 1990. What is the name? Reputation building and corporate strategy. Academy of Management Journal 33: 233-58.

Garcia Pont, Carlos, and Nitin Nohria. 2002. Local versus global mimetism: The dynamics of alliance formation in the automobile industry. Strategic Management Journal 23: 307-21. [CrossRef]

Gentry, Richard, Thomas Dalziel, and Mark Jamison. 2013. Who Do Start-Up Firms Imitate? A Study of New Market Entries in the CLEC Industry. Journal of Small Business Management 51: 525-38. [CrossRef]

George, Gerard, and Adam Bock. 2011. The business model in practice and its implications for entrepreneurship research. Entrepreneurship Theory and Practice 35: 83-111. [CrossRef]

Gimeno, Javier, Timothy Folta, Arnold Cooper, and Carolyn Woo. 1997. Survival of the fittest? Entrepreneurial human capital and the persistence of underperforming firms. Administrative Science Quarterly 42: 750-83. [CrossRef]

Greve, Henrich. 2000. Market Niche Entry Decisions: Competition, Learning and Strategy in Tokyo Banking, 1894-1936. Academy of Management Journal 43: 816-36.

Guo, Hai, Jing Zhao, and Jintong Tang. 2013. The role of top managers' human and social capital in business model innovation. Chinese Management Studies 7: 447-69. [CrossRef]

Haunschild, Pamela, and Anne Miner. 1997. Modes of Interorganizational Imitation: The Effects of Outcome Salience and Uncertainty. Administrative Science Quarterly 42: 472-500. [CrossRef]

Haunschild, Pamela. 1993. Interorganizational Imitation: The Impact of Interlocks on Corporate Acquisition Activity. Administrative Science Quarterly 38: 564-92. [CrossRef]

Haveman, Heather. 1993. Follow the Leader: Mimetic Isomorphism and Entry into New Markets. Administrative Science Quarterly 38: 593-627. [CrossRef]

Heckathorn, Douglas. 1997. Respondent-driven sampling: A new approach to the study of hiddenpopulations. Social Problems 44: 174-99. [CrossRef]

Helpman, Elhanan. 1993. Innovation, Imitation and Intellectual Property Rights. Econometrica 61: 1247-80. [CrossRef] 
Honjo, Yuji. 2004. Growth of New Start-up Firms: Evidence from the Japanese Manufacturing Industry. Applied Economics 36: 343-55. [CrossRef]

Hung, Humphry, and Reuben Mondejar. 2005. Corporate directors and entrepreneurial innovation: An empirical study. The Journal of Entrepreneurship 14: 117-29. [CrossRef]

Johnson, Mark, Clayton Christensen, and Henning Kagermann. 2008. Reinventing your business model. Harvard Business Review 86: 57-68.

Kato, Masatoshi, Hiroyuki Okamuro, and Yuji Honjo. 2015. Does Founders' Human Capital Matter for Innovation? Evidence from Japanese Start-ups. Journal of Small Business Management 53: 114-28. [CrossRef]

Kim, Linsu. 1997. Imitation to Innovation: The Dynamics of Korea's Technological Learning. Boston: Harvard Business School Press.

Kim, Woojae, Yongjiang Shi, and Mike Gregory. 2004. Transition from Imitation to Innovation: Lessons from a Korean Multinational Corporation. International Journal of Business 9: 329-46.

Knott, Anne Marie. 2003. The organizational routines factor market paradox. Strategic Management Journal 24: 929-43. [CrossRef]

Koellinger, Philipp, and Roy Thurik. 2012. Entrepreneurship and the business cycle. Review of Economics and Statistics 94: 1143-56. [CrossRef]

Kogut, Bruce, and Udo Zander. 1992. Knowledge of the Firm, Combinative Capabilities and the Replication of Technology. Organization Science 3: 301-441. [CrossRef]

Kohli, Ajay, and Bernard Jaworski. 1990. Market orientation: The construct, research propositions and managerial implications. Journal of Marketing 54: 1-18. [CrossRef]

Kraaijenbrink, Jeroen, J. C. Spender, and Aard Groen. 2010. The resource-based view: A review and assessment of its critiques. Journal of Management 36: 349-72. [CrossRef]

Lackéus, Martin, and Karen Williams Middleton. 2015. Venture creation programs: Bridging entrepreneurship education and technology transfer. Education and Training 57: 48-73. [CrossRef]

Lane, Peter, and Michael Lubatkin. 1998. Relative absorptive capacity and Interorganizational learning. Strategic Management Journal 19: 461-77. [CrossRef]

Lee, Ruby, and Kevin Zheng Zhou. 2012. Is Product Imitation Good for Firm Performance? An Examination of Product Imitation Types and Contingency Factors. Journal of International Marketing 20: 1-16. [CrossRef]

Lévesque, Moren, and Dean Shepherd. 2004. Entrepreneurs' Choice of Entry Strategy in Emerging and Developed Markets. Journal of Business Venturing 19: 29-54. [CrossRef]

Levitt, Theodore. 1966. Innovative Imitation. Harvard Business Review 44: 63-70.

Lieberman, Marvin, and David Montgomery. 1988. First mover advantages. Strategic Management Journal 9: 41-58. [CrossRef]

Lieberman, Marvin, and Shigeru Asaba. 2006. Why do firms imitate each other? Academy of Management Review 31: 366-85. [CrossRef]

Link, Albert, and John Neufeld. 1986. Innovation versus Imitation: Investigating Alternatives R\&D Strategies. Applied Economics 18: 1359-63.

Mansfield, Edwin. 1961. Technical Change and the Rate of Imitation. Econometrica 61: 741-66. [CrossRef]

March, James, and Johan Olsen. 1976. Ambiguity and Choice in Organizations. Bergen: Universitetsforlaget.

Marvel, Matthew, and G. T. Lumpkin. 2007. Technology Entrepreneurs' Human Capital and its Effects on Innovation Radicalness. Entrepreneurship Theory and Practice 31: 807-28. [CrossRef]

Meyer, John, and Brian Rowan. 1977. Institutionalized Organizations: Formal Structure as Myth and Ceremony. American Journal of Sociology 83: 340-63. [CrossRef]

Mian, Sarfraz, Wadid Lamine, and Alain Fayolle. 2016. Technology Business Incubation: An overview of the state of knowledge. Technovation 50: 1-12. [CrossRef]

Mustar, Philippe, Mike Wright, and Bart Clarysse. 2008. University spin-off firms: Lessons from ten years of experience in Europe. Science and Public Policy 35: 67-80. [CrossRef]

Neyens, Inge, Dries Faems, and Luc Sels. 2010. The impact of continuous and discontinuous alliance strategies on startup innovation performance. International Journal of Technology Management 52: 392-410. [CrossRef]

Niosi, Jorge. 1999. The Diffusion of Organizational Innovations. Towards an Evolutionary Approach. In Institutions and the Evolution of Capitalism: Implications of Evolutionary Economics. Edited by Groenewegen John. Cheltenham: Elgar, pp. 109-21. 
Nunnally, Jum, Paul Knott, Albert Duchnowski, and Ronald Parker. 1967. Pupillary response as a general measure of activation. Perception \& Psychophysics 2: 149-55.

Ordanini, Andrea, Gaia Rubera, and Robert DeFilippi. 2008. The many moods of organizational imitation: A critical review. International Journal of Management Reviews 10: 375-98. [CrossRef]

Orhan, Muriel, and Don Scott. 2001. Why women enter into entrepreneurship: An explanatory model. Women in Management Review 16: 232-47. [CrossRef]

Papulová, Zuzana, and Matej Mokroš. 2007. Importance of managerial skills and knowledge in management for small entrepreneurs. eLeader, 1-8.

Pretorius, Marius, S. M. Millard, and M. E. Kruger. 2005. Creativity, innovation and implementation: Management experience, venture size, life cycle stage, race and gender as moderators. South African Journal of Business Management 36: 55-68. [CrossRef]

Rhee, Mooweon, Young Choon Kim, and Joon Han. 2006. Confidence in imitation: Niche-width strategy in UK automobile industry. Management Science 52: 501-13. [CrossRef]

Rogers, Everett. 1995. Diffusion of Innovations. New York: Free Press.

Schnaars, Steven. 1994. Managing Imitation Strategies, How Later Entrants Seize Markets from Pioneers. New York: Free Press.

Shane, Scott, and S. Venkataraman. 2000. The promise of entrepreneurship as a field of research. Academy of Management Review 25: 217-26. [CrossRef]

Shane, Scott. 2000. Prior knowledge and the discovery of entrepreneurial opportunities. Organization Science 11: 448-69. [CrossRef]

Shenkar, Oded. 2010. Imitation Is More Valuable Than Innovation. Harvard Business Review 88: 28-29.

Shankar, Venkatesh, Gregory Carpenter, and Lakshman Krishnamurthi. 1998. Late mover advantage: How innovative late entrants outsell pioneers. Journal of Marketing Research 35: 54-70. [CrossRef]

Shepherd, Dean, and Dawn DeTienne. 2005. Prior knowledge, potential financial reward, and opportunity identification. Entrepreneurship Theory and Practice 29: 91-112. [CrossRef]

Short, Jeremy, David Ketchen, Christopher Shook, and Duane Ireland. 2010. The concept of "opportunity" in entrepreneurship research: Past accomplishments and future challenges. Journal of Management 36: 40-65. [CrossRef]

Sinclair, Peter. 1990. The Economics of Imitation. Scottish Journal of Political Economy 17: 113-44. [CrossRef]

Sine, Wesley, Heather Haveman, and Pamela Tolbert. 2005. Risky Business? Entrepreneurship in the New Independent-Power Sector. Administrative Science Quarterly 50: 200-32. [CrossRef]

Sirmon, David G., Michael A. Hitt, R. Duane Ireland, and Brett Anitra Gilbert. 2011. Resource orchestration to create competitive advantage: Breadth, depth, and life cycle effects. Journal of Management 37: 1390-412. [CrossRef]

Smith, Doug, Adam Scaife, and Ben Kirtman. 2012. What is the current state of scientific knowledge with regard to seasonal and decadal forecasting? Environmental Research Letters 7: 1-11. [CrossRef]

Song, Zhi Hong. 2015. Organizational learning, absorptive capacity, imitation and innovation: Empirical analyses of 115 firms across China. Chinese Management Studies 9: 97-113. [CrossRef]

Spender, John Christopher. 2014. Business Strategy: Managing Uncertainty, Opportunity and Enterprise. Oxford: Oxford University Press.

Spender, John Christopher, Vincenzo Corvello, Michele Grimaldi, and Pierluigi Rippa. 2017. Startups and open innovation: A review of the literature. European Journal of Innovation Management 20: 4-30. [CrossRef]

Staniewski, Marcin. 2016. The contribution of business experience and knowledge to successful entrepreneurship. Journal of Business Research 69: 5147-52. [CrossRef]

Strang, David, and Nancy Tuma. 1993. Spatial and temporal heterogeneity in diffusion. American Journal of Sociology 99: 614-39. [CrossRef]

Subramaniam, Mohan, and Mark Youndt. 2005. The influence of intellectual capital on the types of innovative capabilities. Academy of Management Journal 48: 450-63. [CrossRef]

Subramaniam, Mohan, and N. Venkatraman. 2001. Determinants of transnational new product development capability: Testing the influence of transferring and deploying tacit overseas knowledge. Strategic Management Journal 22: 359-78. [CrossRef]

Tang, Jintong, K. Michele Kacmar, and Lowell Busenitz. 2012. Entrepreneurial alertness in the pursuit of new opportunities. Journal of Business Venturing 27: 77-94. [CrossRef] 
Teece, David, Gary Pisano, and Amy Shuen. 1997. Dynamic Capabilities and Strategic Management. Strategic Management Journal 18: 509-33. [CrossRef]

Thorpe, Richard, Robin Holt, Allan Macpherson, and Luke Pittaway. 2005. Using knowledge within small and medium-sized firms: A systematic review of the evidence. International Journal of Management Reviews 7: 257-81. [CrossRef]

Tsai, Wenpin, and Sumantra Ghoshal. 1998. Social capital and value creation: The role of intrafirm networks. Academy of Management Journal 41: 464-78.

Tsui, Auch, and Lai Si. 2003. Learning Strategies of Small and Medium-sized Chinese Family Firms: A comparative study of two suppliers in Singapore. Management Learning 34: 201-20. [CrossRef]

Valdani, Enrico, and Alessandro Arbore. 2007. Strategies of imitation: An insight. Problems and Perspectives in Management 5: 198-205.

Van de Ven, Andrew H. 1986. Central problems in the management of innovation. Management Science 32: 590-607. [CrossRef]

Watson, Kathryn, Sandra Hogarth Scott, and Nicholas Wilson. 1998. Small business start-ups: Success factors and support implications. International Journal of Entrepreneurial Behaviour \& Research 4: 217-38.

Wennekers, Sander, and Roy Thurik. 1999. Linking entrepreneurship and economic growth. Small Business Economics 13: 27-55. [CrossRef]

Weterings, Anet, and Ron Boschma. 2009. Does spatial proximity to customers matter for innovative performance? Evidence from the Dutch software sector. Research Policy 38: 746-55. [CrossRef]

Wu, Jie, Kathryn Rudie Harrigan, Siah Hwee Ang, and Zefu Wu. 2019. The impact of imitation strategy and R\&D resources on incremental and radical innovation: Evidence from Chinese manufacturing firms. The Journal of Technology Transfer 44: 210-30.

Wymer, Scott, and Elizabeth Regan. 2005. Factors influencing e-commerce adoption and use by small and medium businesses. Electronic Markets 15: 438-53. [CrossRef]

Zahra, Shaker, R. Duane Ireland, and Michael A. Hitt. 2000. International expansion by new venture firms: International diversity, mode of market entry, technological learning and performance. The Academy of Management Journal 43: 925-50.

Zhang, Shi, and Arthur Markman. 1998. Overcoming the early entrant advantage: The role of alignable and nonalignable differences. Journal of Marketing Research 35: 413-26. [CrossRef]

Zhou, Kevin Zheng, and Fang Wu. 2010. Technological capability, strategic flexibility, and product innovation. Strategic Management Journal 31: 547-61. [CrossRef]

Zhou, Kevin Zheng. 2006. Innovation, imitation, and new product performance: The case of China. Industrial Marketing Management 35: 394-402. [CrossRef]

Zott, Christoph, and Raphael Amit. 2010. Business model design: An activity system perspective. Long Range Planning 43: 216-26. [CrossRef]

(C) 2020 by the authors. Licensee MDPI, Basel, Switzerland. This article is an open access article distributed under the terms and conditions of the Creative Commons Attribution (CC BY) license (http://creativecommons.org/licenses/by/4.0/). 